Emir. J. Agric. Sci. 2005. 17 (1): 10-22

http://www.cfa.uaeu.ac.ae/Research/EJAS.htm

\title{
Use of sicklepod, Senna obtusifolia (L.) Irwin and Barneby, as mulch interplant in cayenne pepper, Capsicum frutescens L., production
}

\author{
Rasheed Olufemi Awodoyin and Sola Ogunyemi
}

Department of Crop Protection and Environmental Biology, University of Ibadan, Nigeria.

\begin{abstract}
The suitability of sicklepod as mulch interplant to smother weeds in the crop interrows and generate mulch in situ in the production of cayenne pepper was investigated on the field in 1997 and 1998 at Ibadan in the dry rainforest of Nigeria. The Senna-interplant treatment was compared with plastic-, grass- and woodchip-mulched treatments, hand weeding control and unweeded control in a randomised complete block design using four replications. Pepper fruit yield from Senna-interplant was similar to those from plastic and grass mulch in 1997, but was significantly $(\mathrm{P}<0.05)$ lower in 1998 . Uncontrolled weed growth reduced fruit yield by $73 \%$ and $78 \%$ in 1997 and 1998, respectively, compared to the mean fruit yield from all mulched treatments. Senna-interplant, plastic, grass and woodchip mulch treatments increased the fruit yield by $21 \%$, $36 \%, 45 \%$, and $11 \%$, respectively, compared to the hand weeding unmulched treatment. Over the two years, the weed control efficiency of the Senna-interplant, plastic, grass and woodchip mulch, and hand weeding treatments relative to unweeded control treatment were $54 \%, 97 \%, 27 \%, 64 \%$, and $88 \%$, respectively. The afternoon temperature of the soil was reduced by the straw mulch types but increased by the plastic mulch. Soil moisture loss was less under all mulch types than in hand weeding and unweeded control treatments. The predominant weeds of the experimental area were Chromolaena odorata (L.) R.M. King \& Robinson, Talinum fruticosum (L.) Juss, Synedrella nodiflora Gaertn and Laportea aestuans (L.) ex Miq with relative importance values 9.8\%, 8.6\%, $8.3 \%$, and $6.3 \%$, respectively. The weed dry weight, topsoil temperature and moisture depletion negatively correlated with the performance of the pepper plants.
\end{abstract}

Key words: Mulching, soil conditions, vegetables, weed control, yield.

\section{Sicklepod (Senna obtusifolia (L.) Irwin and Barneby) لمتخدل نبلت كزراعة تخلية بينية في إنتاج الفلى cayenne pepper (Capsicum frutescens L.) رشيد أودونسسولا أوغلنيمي \\ قسم وقلية النبل والبيولوجيا البيئية، جامعة عبدلن، نيجيربا}

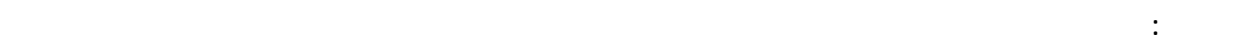

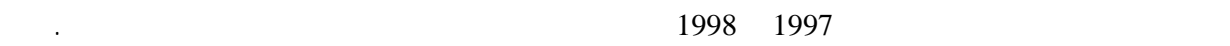

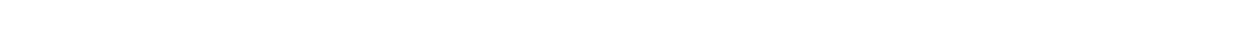

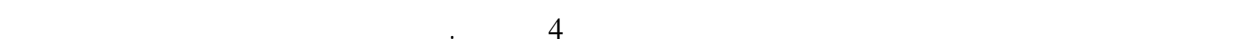

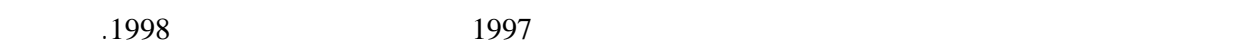

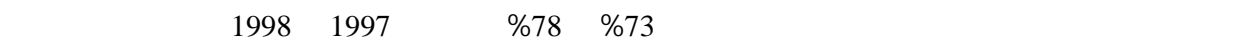

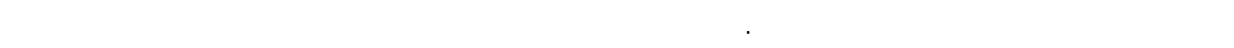
الغثب إلى زياة محصول الثمار بنسبة 21\% و 36\% و 45\% و 11\%، على التوالي، مقارنة بمعلملة الإزالة اليدوية

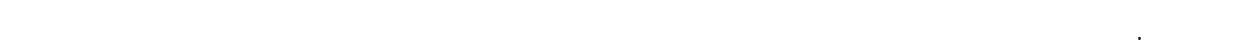

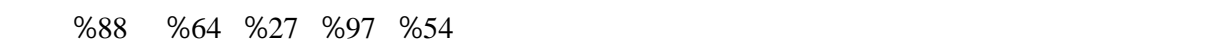




\section{R. O. Awodoyin \& S. Ogunyemi}

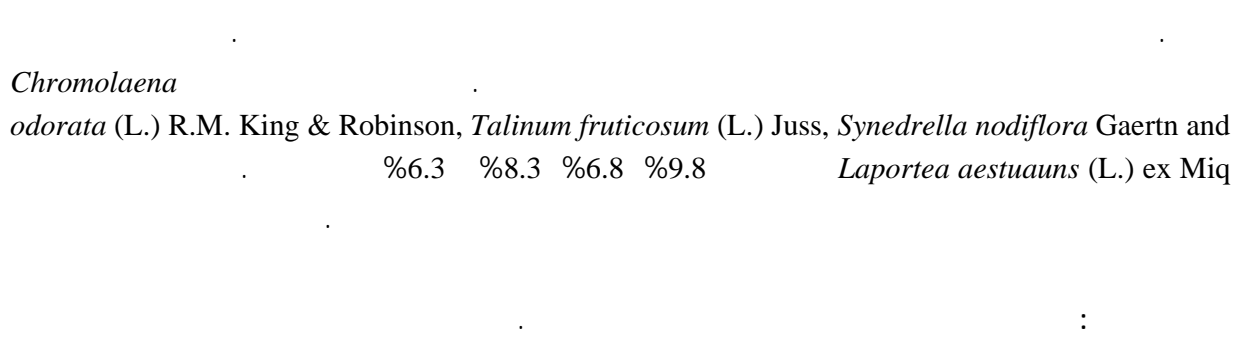

\section{Introduction}

Peppers (family Solanaceae) provide spice, essential vitamins and minerals, and add colour to foods. They are ranked as the third most important vegetable after onion and tomatoes in Nigeria (Fawusi, 1978). The long-fruited cayenne pepper, Capsicum frutescens L. widely cultivated in Nigeria for its good storability, closes canopy slowly and may succumb to weed competition in the early stages of growth.

Peppers require well drained soils with good organic matter content, which on tropical soils is supplied by mulch that accumulates on the soil during the fallow phase of the shifting cultivation farming practice. Shifting cultivation offers the most ecologically stable and environment friendly form of agriculture in the tropical rainforest (Kang and Ghuman, 1991). However, mulch supply from this system has become inadequate due to shortened fallow period resulting from high rate of population growth and restriction of access to fertile lands placed by government's land tenure policies (Kotschi, 1990).

Mulching as a farm practice has its benefits in the control of weeds, amelioration of soil temperature, conservation of soil moisture, protection of soil micro/macrofauna and flora, control of soil erosion, improvement of soil structure, enhancement of soil organic matter content, etc (Salau et al., 1992; Owaiye, 1993). Aiyelaagbe and
Fawusi (1986) reported that due to high soil water potential under mulch, the mulched pepper plants grew significantly larger than unmulched plants. Also, Liu et al. (1987) reported that tomato and cayenne pepper produced under drip irrigation responded positively to mulching. Hudu et al. (2002) reported that soil temperature difference between $0700 \mathrm{~h}$ and $1300 \mathrm{~h}$ was two times lower in mulched treatments than in unmulched control treatment in the semi-arid zone of Nigeria.

Despite the advantages of mulching, generation of mulch ex situ to supplement fallow mulch enjoys low adaptability among farmers because of high labour requirement to collect, transport and apply the mulch (Kang et al., 1981). To circumvent the intractable problem of high labour requirement, the in situ sourcing by interplanting the crop with erect-stemmed, fast-growing, deeprooting and good biomass-producing legume and non-legume shrubs was recommended as one of the alternatives to shifting cultivation (Kotschi, 1990; Akobundu, 1993). The use of legume shrubs may be more acceptable to farmers than alley cropping, a tree-based intensive fallow management system, because it is adaptable to the farmers' intercropping system and prevents introducing aggressive hedgerow tree species.

This report is the result of the investigation carried out on the 
Emir. J. Agric. Sci. 2005.17 (1): 10-22

http://www.cfa.uaeu.ac.ae/Research/EJAS.htm

suitability of Senna obtusifolia (L.) Irwin \& Barneby as mulch interplant to smother weeds in the crop interrows and to generate mulch in situ for the production of $C$. frutescens; Sombo (Nigeria), Tabasco (Benin)]. The influence of the mulch on soil temperature and soil moisture dynamics was also reported. Sicklepod is a widely distributed native species with several ethnobotanical benefits among the local populace (Awodoyin and Ogunyemi, 2003) and may be more acceptable to farmers in Africa than introduced species.

\section{Materials and Methods}

The study was carried out in the early season of 1997 and 1998 in the crop garden of the Department of Crop Protection and Environmental Biology,
University of Ibadan, Nigeria $\left(7^{\circ} 30^{\prime} \mathrm{N}\right.$; $3^{0}$ 54'E; $234 \mathrm{~m}$ above sea level). The land used for the study was under bush fallow dominated by Chromolaena odorata (L.) R.M. King \& Robinson for three years, and the last crop planted on it was pepper. The soil in the study site was an acidic (pH 5.7 in 1997, $\mathrm{pH} 6.1$ in 1998) sandy clay loam containing $3.21 \%$ organic matter, $0.23 \%$ total N, $5.20 \mathrm{ppm}$ $\mathrm{P}$ and $0.32 \mathrm{meq} / 100 \mathrm{~g} \mathrm{~K}$ in 1997 and $2.51 \%$ organic matter, $0.18 \%$ total $\mathrm{N}$, $4.60 \mathrm{ppm} \mathrm{P}$ and $0.34 \mathrm{meq} / 100 \mathrm{~g} \mathrm{~K}$ in 1998. The rainfall distribution in the two years was bimodal with peaks in June and October. The total rainfall was $1285.8 \mathrm{~mm}$ distributed over 131 days in 1997 and $794.2 \mathrm{~mm}$ distributed over 118 days in 1998 (Table 1). The rainfall: evaporation ratio was 1:1.06 in 1997 and 1:0.64 in 1998.

Table 1. Rainfall distribution and pan evaporation in Ibadan, Southwest Nigeria in 1997 and 1998.

\begin{tabular}{lcccccccc}
\hline & \multicolumn{2}{c}{ Rainfall $(\mathbf{m m})$} & & \multicolumn{2}{c}{ Number of Rainy days } & & \multicolumn{2}{c}{ Pan-evaporation (mm) } \\
\cline { 2 - 3 } Months & $\mathbf{1 9 9 7}$ & $\mathbf{1 9 9 8}$ & & $\mathbf{1 9 9 7}$ & $\mathbf{1 9 9 8}$ & & $\mathbf{1 9 9 7}$ & $\mathbf{1 9 9 8}$ \\
\hline January & 0.6 & 0.0 & & 1 & 0 & & 111.03 & 109.03 \\
February & 0.0 & 2.8 & & 0 & 1 & & 146.09 & 123.63 \\
March & 105.4 & 8.0 & & 10 & 3 & & 139.25 & 143.21 \\
April & 150.9 & 54.4 & & 10 & 9 & & 117.56 & 131.90 \\
May & 155.1 & 82.8 & & 19 & 14 & & 116.75 & 116.66 \\
June & 177.3 & 158.1 & & 19 & 17 & & 90.87 & 104.59 \\
July & 71.7 & 71.9 & & 12 & 17 & & 63.89 & 81.88 \\
August & 96.0 & 50.8 & & 17 & 14 & & 60.54 & 66.82 \\
September & 195.7 & 143.6 & & 17 & 16 & & 90.56 & 77.41 \\
October & 261.0 & 178.7 & & 16 & 17 & & 99.92 & 86.98 \\
November & 38.3 & 31.7 & & 8 & 5 & & 88.55 & 109.98 \\
December & 33.8 & 11.4 & & 2 & 5 & & 88.80 & 94.28 \\
Total & 1285.8 & 794.2 & & 131 & 118 & & 1213.81 & 1246.37 \\
\hline
\end{tabular}

Source: IITA Central Station, Ibadan.

The pepper variety used for the study is a woody, branched and short-lived perennial, which grows to about $1.5 \mathrm{~m}$ high. The fruit is elongated (4 


\section{R. O. Awodoyin \& S. Ogunyemi}

$\mathrm{x} 1 \mathrm{~cm}$ ), very pungent and easily dried (Messiaen, 1992). The seed used was obtained from the National Horticultural Research Institute, Ibadan, Nigeria.

Pepper seedlings at age 8 weeks were transplanted to a well-prepared field on 23rd May for the 1997 trial and 19th June for the 1998 trial. Transplanting was done at a spacing $0.4 \times 0.6 \times 0.9 \mathrm{~m}$ in double rows to achieve a population of 33,333 plants/ha and 24 plants/plot. Two weeks after transplanting (WAT), the entire field was hoe-weeded and enriched with $350 \mathrm{~kg} / \mathrm{ha}$ (10.5 g/plant) of NPK 15-15-15 fertilizer. Fertilizer application was repeated 6 WAT at the rate of 700 $\mathrm{kg} / \mathrm{ha}$ (21 g/plant). The fertilizer was applied by ringing at $5 \mathrm{~cm}$ from the base of each plant. Lamdacyalothrin (karate) was applied every fortnight using knapsack sprayer at the rate of 1 litre/ha (50 ml/15-litre of water) to control insect pests. There were six treatments, namely Senna interplant mulch, plastic mulch (0.25 $\mu \mathrm{m}$ thick black-grey polythene sheet), grass (Pennisetum polystachion (L.) Schult) mulch, woodchip mulch, unmulched hand weeding control and unweeded control. The treatments were arranged in a randomised complete block design (RCBD) replicated four times. Individual plot measured $5 \mathrm{~m} \times 2 \mathrm{~m}$ and adjacent plots were separated by a $1.4-\mathrm{m}$ alley way.

The Senna interplant was established at a spacing of $5 \mathrm{~cm} \times 15 \mathrm{~cm}$ within the $0.6 \mathrm{~m}$ and $0.9 \mathrm{~m}$ interrow spaces (alleys) of the pepper seedlings. Acid-scarified seeds of S. obtusifolia were hand-sown $30 \mathrm{~cm}$ away from the pepper row to have one row and three rows in the $0.6 \mathrm{~m}$ and $0.9 \mathrm{~m}$ pepper alleys, respectively. Three seeds were sown per hill and emerged seedlings were hand-thinned to one per hill at one week after sowing (WAS) to produce a final density of 20 plants per $m$ of row. The Senna plots were weeded once at 4 WAS. The established Senna plants were pruned back to $50 \mathrm{~cm}$ height three times at 8,12 and 16 WAS. The prunings so generated within each plot were weighed were weighed and used to mulch the pepper stands. At second pruning, the single row of $S$. obtusifolia in the $60 \mathrm{~cm}$ pepper alley was pruned back to the ground level to give the pepper plants ample space for canopy development.

With the exception of plastic mulch, that was laid with the grey surface up just before transplanting, other mulch treatments were applied at 2 WAT the pepper seedlings, when the general weeding and application of the first fertilizer dose had been done. Holes were made at the pre-marked points in plastic mulch to aid transplanting of pepper seedlings to the field. The grass mulch, obtained from the clippings of $P$. polystachion, was collected from the nearby bush fallow and laid to a thickness of $2 \mathrm{~cm}$. The grass mulch was replenished every four weeks because of the observed rapid decomposition. Woodchip mulch was obtained from Teak timber (Tectona grandis L.) sawn at the Wood Technology Workshop in the Department of Forest Resources Management, the University of Ibadan, Nigeria. The woodchip mulch was laid to a thickness of $2 \mathrm{~cm}$, and was not replenished during each trial. The woodchip plots took equivalent of $6 \mathrm{t} / \mathrm{ha}$ dry matter (DM) per annum. The grass mulch was laid three times at an equivalent of $10 \mathrm{t} / \mathrm{ha}$ fresh weight (FW) each time, giving a total of $30 \mathrm{t} / \mathrm{ha} \mathrm{FW}$ per annum. The total Senna pruning recurrently generated per annum within pepper plots in 1997 and 1998 were 23.72 t/ha and 15.33 t/ha FW, respectively (Table 2). Hand-weeded plots were maintained by hand-hoeing every 
Emir. J. Agric. Sci. 2005. 17 (1): 10-22 http://www.cfa.uaeu.ac.ae/Research/EJAS.htm

fortnight for the duration of the study while unweeded plots were left unweeded from 2 WAT the pepper seedlings.

Table 2. Amount of Senna obtusifolia pruning [tonne $\mathrm{FW} / \mathrm{ha}$.] generated within pepper plots in 1997 and 1998. Values shown are mean $\pm S$. E. [n=4].

\begin{tabular}{ccc}
\hline Pruning & $\mathbf{1 9 9 7}$ & $\mathbf{1 9 9 8}$ \\
\hline $1^{\text {st }}$ & $8.68 \pm 2.64$ & $4.09 \pm 1.69$ \\
$2^{\text {nd }}$ & $9.79 \pm 1.93$ & $6.13 \pm 2.27$ \\
$3^{\text {rd }}$ & $5.25 \pm 1.47$ & $5.11 \pm 1.38$ \\
\hline
\end{tabular}

At 16 WAT in each trial, three pepper plants were randomly selected at the centre of each plot and tagged for measurements of plant height and canopy width. The number and fresh weight of fruits were recorded weekly for 12 weeks starting from 13 WAT, and pooled for analyses. At 16 WAT, weed samples were collected from four $25 \mathrm{~cm}$ x $25 \mathrm{~cm}$ wooden quadrats placed randomly along the $0.9 \mathrm{~m}$ pepper alley in each plot for identification by species and density counts. The relative density (RD), relative frequency (RF) and relative importance value (RIV) were determined for each species following Greig-Smith (1964).

The aboveground weed plants that rooted within each quadrat were collected, oven-dried at $80^{\circ} \mathrm{C}$ for 48 hours and weighed to determine the weed dry weight. The weed control efficiency (WCE) was determined as the percentage of the difference between the weed dry weight of a treatment and that of the unweeded control as related to the weed dry weight of the unweeded control following Gill and Kumar (1966).

Soil temperature under mulch was measured in triplicate with a long-stemmed mercury-in-glass thermometer calibrated to $50^{\circ} \mathrm{C}$. The thermometer was installed at $5 \mathrm{~cm}$ and 15 $\mathrm{cm}$ soil depth in each plot and measurements were taken at 0800,1200 , 1600 and 1800 h. on 26th, 27th, 28th and 29th June, 1997 and 27th, 28th and 29th June, 1998.

The period of dry spell was targeted in $1997\left(2^{\text {nd }}-29^{\text {th }}\right.$ July $)$ and 1998 ( $5^{\text {th }}$ August $-6^{\text {th }}$ September) to monitor the soil moisture depletion under the mulch types. The percentage moisture content of the soil samples was assessed on $2^{\text {nd }}, 12^{\text {th }}$ and $29^{\text {th }}$ July, 1997, and $6^{\text {th }}$ August and $6^{\text {th }}$ September, 1998 to monitor the trend of moisture depletion in the soil. Soil samples from the $0-10 \mathrm{~cm}$ depths were collected for the determination of percent soil moisture content according to Allen et al. (1976).

All data collected were analysed statistically by using Analysis of Variance (ANOVA) procedures according to Gomez and Gomez (1984). Data for the two years were pooled for the growth, yield and weed dry weight parameters and split-plot ANOVA procedure adopted for the analysis with the years (2) as the main factor and treatments (6) as the minor factor. The weed dry weight data were subjected to square root transformation according to Little and Hills (1978). Mean separation was made at the $5 \%$ level of probability using the Least Significant Difference (LSD) test. The growth and yield parameters, weed dry weight, 1600 $\mathrm{h}$ soil temperature at $5 \mathrm{~cm}$ depth and moisture depletion were compared using correlation coefficient ( $\mathrm{r}$ ) according to Gomez and Gomez (1984). 


\section{R. O. Awodoyin \& S. Ogunyemi}

\section{Results}

Pepper growth and yield

In all the growth and yield parameters studied the performance of pepper plants was significantly $(P=0.05)$ better in 1997 than 1998 (Table 3). The Senna-mulched plants were significantly $(P=0.001)$ taller than other plants, and the grass-mulched plants had significantly $(P=0.05)$ wider canopy than other plants.

The grass-mulched plants were the best with regards to the yield parameters. The number of fruits per plant and the fruit weight per hectare were significantly $(P=0.05)$ higher in mulched plants and hand weeded plants than the unweeded plants (Table 3).

Table 3. The performance of cayenne pepper and weed dry eight as affected by various mulch treatments during 1997 and 1998 main cropping season $(r=4)$.

\begin{tabular}{|c|c|c|c|c|c|c|c|}
\hline \multirow[b]{2}{*}{ Year } & \multicolumn{7}{|c|}{ Mulch Types } \\
\hline & $\begin{array}{l}\text { Senna- } \\
\text { interplant }\end{array}$ & Plastic & Grass & Woodchip & Handweeding & Unweeded & $\begin{array}{l}\text { Year } \\
\text { Mean }\end{array}$ \\
\hline \multicolumn{8}{|c|}{ Plant height (cm) } \\
\hline 1997 & 74.8 & 69.3 & 74.4 & 56.7 & 65.3 & 50.2 & 65.1 \\
\hline 1998 & 62.9 & 53.7 & 47.9 & 57.5 & 54.9 & 38.6 & 52.6 \\
\hline Mulch Mean & 68.9 & 61.5 & 61.2 & 57.1 & 60.1 & 44.4 & \\
\hline
\end{tabular}

The LSD at the $5 \%$ level of significance to compare years $=\mathbf{3 . 7}$; mulches (averaged) $=\mathbf{6 . 7}$; mulches (same year $)=$ 9.6. $\mathrm{CV}($ year $)=6.8 \%$; CV $($ mulch $)=11.9 \%$.

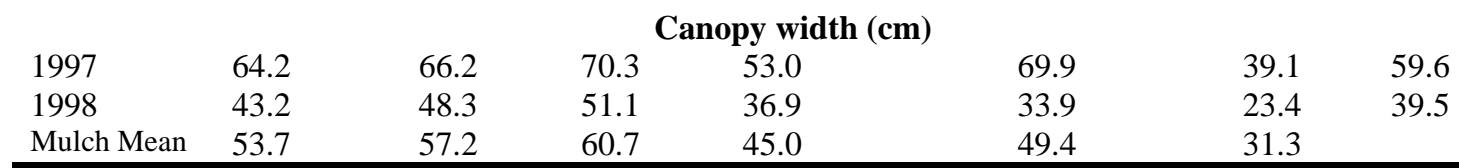

LSD at the $5 \%$ level of significance to compare years $=7.7$; mulches (averaged) $=\mathbf{5 . 5}$; mulches (same year) = 7.8. $\mathrm{CV}$ (year) $=17.0 \%$; CV $($ mulch $)=10.9 \%$.

\begin{tabular}{llllllll} 
& \multicolumn{7}{c}{ Number of fruits per plant } \\
1997 & 278.5 & 307.9 & 405.9 & 251.8 & 257.3 & 94.8 & 266.0 \\
1998 & 199.2 & 238.0 & 297.2 & 207.5 & 178.1 & 66.9 & 197.8 \\
Mulch Mean & 238.8 & 273.0 & 351.5 & 229.7 & 217.7 & 80.9 & \\
\hline
\end{tabular}

LSD at the $5 \%$ level of significance to compare years = 17.2; mulches (averaged) = 5.5; mulches (same year $)=$ 7.8. $\mathrm{CV}$ (year) $=8.1 \%$; CV $($ mulch $)=29.2 \%$.

\begin{tabular}{llllclll} 
& \multicolumn{7}{c}{ Fruit yield (t/ha) } \\
1997 & 26.7 & 31.0 & 36.7 & 21.7 & 21.0 & 7.7 & 24.1 \\
1998 & 18.1 & 24.0 & 26.8 & 17.9 & 14.5 & 4.7 & 17.7 \\
Mulch Mean & 22.4 & 27.5 & 31.8 & 19.8 & 17.8 & 6.2 & \\
\hline
\end{tabular}

LSD at the $5 \%$ level of significance to compare years = 1.3; mulches (averaged) $=\mathbf{5 . 8}$; mulches (same year)

= 8.2. $\mathrm{CV}($ year $)=6.9 \%$; CV $($ mulch $)=27.4 \%$.

\begin{tabular}{llllllll}
\multicolumn{7}{c}{$*$ Weed dry weight $\left(\mathbf{g} / \mathbf{m}^{2}\right)$} \\
1997 & 10.4 & 0.7 & 17.1 & 9.7 & 3.6 & 22.7 & 10.7 \\
1998 & $(106.8)$ & $(0)$ & $(292.1)$ & $(94.6)$ & $(13.2)$ & $(578.1)$ & 10.4 \\
& 11.1 & 0.7 & 16.9 & 7.1 & 2.6 & 24.1 & $(584.9)$ \\
Mulch Mean & $(124.0)$ & $(0)$ & $(289.5)$ & $(50.1)$ & $(6.8)$ & 23.4 \\
\hline
\end{tabular}


The cumulative number of fruits per plant and cumulative fruit weight per hectare had similar trend in the two years with grass mulch $>$ plastic mulch $>$ Senna interplant $>$ woodchip mulch $>$ hand weeding $>$ unweeded. The Senna-, plastic-, and grassmulched plants had comparable yield in 1997. However, in 1998 the fruit yield of Sennamulched plants was significantly $(P=0.05)$ lower than that of plastic- and grass-mulched plants. On the other hand, the fruit yield of woodchip-mulched and handweeded plants were similar in both years.

The unweeded plants were significantly $(P=0.05)$ inferior in terms of all growth and yield parameters. Interaction between year and mulch was not significant with regards to the canopy width, and the yield parameters, but was significant $(P=0.05)$ with regards to the height growth and weed dry weight.

Compared to mean fruit yield from all mulched treatments, uncontrolled weed reduced pepper fruit yield by about 73\% and $78 \%$ in 1997 and 1998 respectively. Compared to handweeded plants, uncontrolled weed growth reduced fruit yield by 63\% and 68\% respectively, in 1997 and 1998 while Senna interplant, plastic-, grassand woodchip-mulched treatments increased the fruit yield by $27 \%, 48 \%, 75 \%$ and $3 \%$ respectively in 1997 and 25\%, 66\%, 85\% and 23\% respectively, in 1998.

Weed growth and weed flora composition

Weed dry weight was considerably low in most mulch treatments (Table 3). The weed dry weight obtained on the plots was in the order unweeded $>$ grass mulch $>$ Sennainterplant $>$ woodchip $>$ handweeding $>$ plastic in the two years. The two years were not significantly different with regards to the weed dry weight but differences among the mulches were highly significant $(P=0.001)$.
The weed control efficiency of Sennainterplant, plastic-, grass- and woodchipmulched, and handweeded treatments were respectively, 54\%, 97\%, 25\%, 57\% and $84 \%$ in 1997 and 54\%, 97\%, 30\%, 71\% and 89\% in 1998.

Of the 27 weed species observed on the experimental site unweeded plot carried 24 (88.9\%) compared to only seven $(25.9 \%)$ on the woodchip-mulched plots (Table 4). The Senna-interplant, grass-mulched and handweeded plots had comparable number of weed species ( $15-16$ or $55.6 \%-59.3 \%)$. The mean weed density per square meter by treatment was in the order unweeded (47.4) > grass-mulched (42.5) > hanweeded (34.9) > Senna-interplant (23.8) > woodchip (13.7). The plastic mulch was free of weeds. The relative importance value ranged from $0.9 \%$ for Potulaca oleracea to $9.8 \%$ for Chromolaena odorata (Table 4). The RIV showed that the species most encountered on the experimental site were Chromolaena odorata (9.8\%), Talinum fruticosum (8.6\%), Synedrella nodiflora (8.3\%) and Laportea aestuans (6.3\%). 


\section{R. O. Awodoyin \& S. Ogunyemi}

Table 4. Mean density $\left(\right.$ no. $\left./ \mathrm{m}^{2}\right)$ of the common weed species encountered in the various mulch treatments and their relative importance values in $1997(n=16)$.

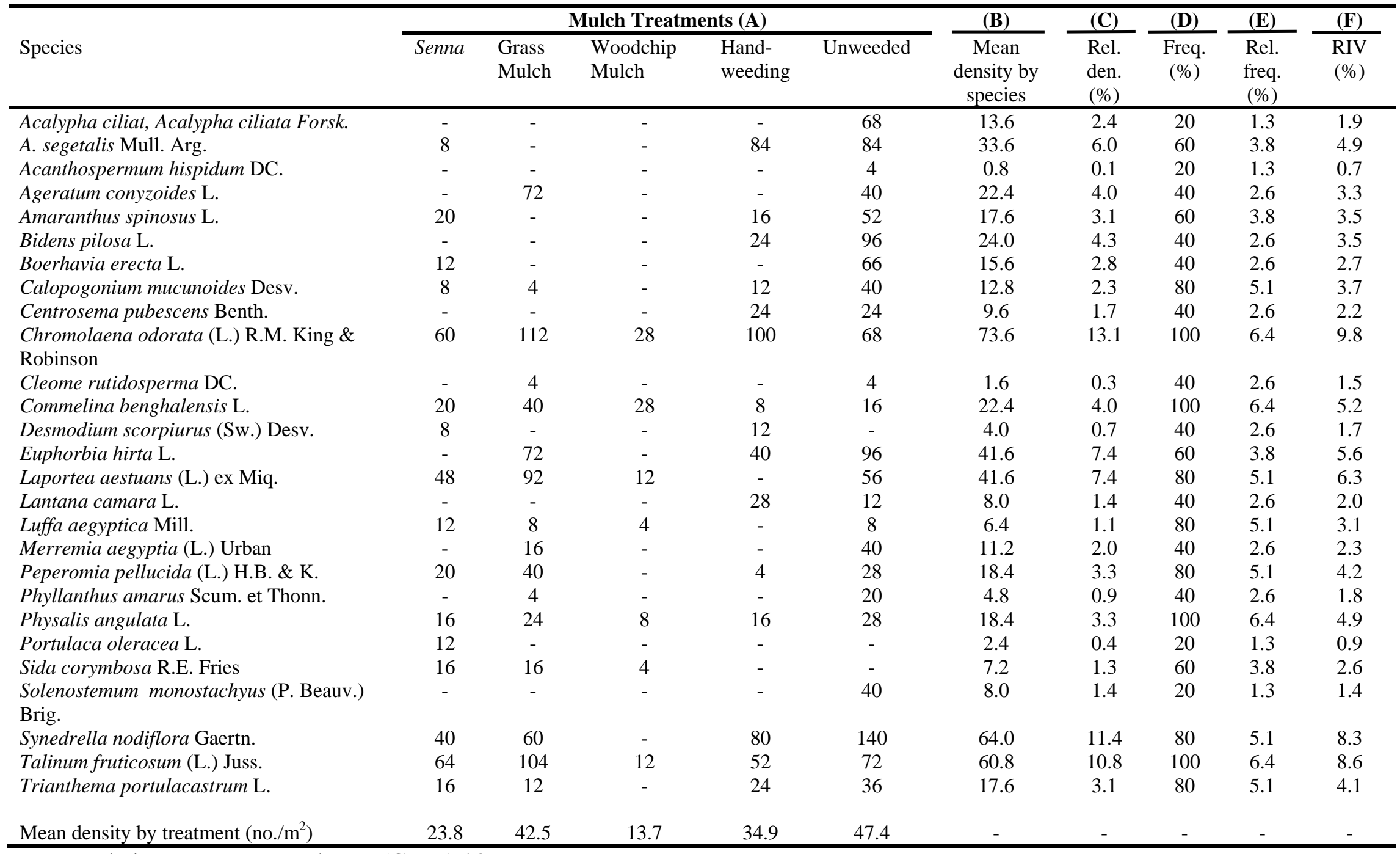

RIV [Relative Importance Value] $=(\mathrm{C}+\mathrm{E}) / 2$ 
Emir. J. Agric. Sci. 2005.17 (1): 10-22

http://www.cfa.uaeu.ac.ae/Research/EJAS.htm

Soil Conditions

increased by plastic mulch, the differences among the various treatments at both depths were not significant in 1997 (Table 5). However, in 1998 the differences among the treatments were significant $(P=0.01)$ except at $0800 \mathrm{~h}$ for the two depths and at $1200 \mathrm{~h}$ for $15 \mathrm{~cm}$ depth.

morning temperatures in both years (Table 5). Though the afternoon (1600 h and $1800 \mathrm{~h}$ ) temperatures of the soil were reduced by plant residue mulches and

Table 5. Effect of mulching on diurnal temperature $\left({ }^{\circ} \mathrm{C}\right)$ at $5 \mathrm{~cm}$ and $15 \mathrm{~cm}$ soil depth in 1997 and 1998.

\begin{tabular}{|c|c|c|c|c|c|c|c|c|}
\hline \multirow[b]{2}{*}{ Mulch Types } & \multicolumn{4}{|c|}{1997} & \multicolumn{4}{|c|}{1998} \\
\hline & 0800h & 1200h & 1600h & 1800h & 0800h & 1200h & $1600 h$ & 1800h \\
\hline \multicolumn{9}{|c|}{$5 \mathrm{~cm}$ depth } \\
\hline Senna Interplant & 26.3 & 28.4 & 30.2 & 29.0 & 28.0 & 30.4 & 33.0 & 32.0 \\
\hline Plastic Mulch & 27.2 & 32.1 & 33.9 & 33.5 & 29.0 & 34.8 & 37.9 & 37.5 \\
\hline Grass Mulch & 26.7 & 29.2 & 31.0 & 30.7 & 28.3 & 31.6 & 34.2 & 33.7 \\
\hline Woodchip & 26.7 & 29.4 & 30.5 & 30.3 & 28.5 & 32.0 & 33.5 & 32.9 \\
\hline Mulch & & & & & & & & \\
\hline Handweeding & 26.7 & 30.4 & 33.2 & 31.0 & 28.1 & 33.3 & 36.8 & 34.2 \\
\hline Unweeded & 26.3 & 28.4 & 30.2 & 29.0 & 28.0 & 30.4 & 33.0 & 31.0 \\
\hline LSD (0.05) & ns & ns & ns & ns & ns & 2.2 & 2.2 & 2.3 \\
\hline \multicolumn{9}{|c|}{15 cm depth } \\
\hline Senna Interplant & 26.2 & 27.8 & 29.6 & 28.7 & 27.8 & 29.7 & 32.2 & 31.9 \\
\hline Plastic Mulch & 27.2 & 29.6 & 31.5 & 31.8 & 29.3 & 32.2 & 34.7 & 35.3 \\
\hline Grass Mulch & 26.6 & 28.2 & 29.6 & 29.8 & 28.7 & 30.5 & 32.3 & 32.9 \\
\hline Woodchip & 26.6 & 28.5 & 29.7 & 29.9 & 28.4 & 31.0 & 32.4 & 32.7 \\
\hline Mulch & & & & & & & & \\
\hline Handweeding & 26.5 & 28.3 & 31.6 & 30.9 & 28.2 & 30.8 & 34.9 & 34.1 \\
\hline Unweeded & 26.2 & 27.8 & 29.5 & 28.7 & 27.8 & 29.6 & 32.1 & 31.5 \\
\hline LSD (0.05) & ns & ns & ns & ns & ns & ns & 2.2 & 2.0 \\
\hline
\end{tabular}

ns $=$ not significant

Although moisture depletion of the soil followed virtually similar trend in both years, the magnitude of moisture loss varied significantly $(P=0.001)$ among the treatments (Table 6). Moisture loss was significantly ( $P=0.001$ ) lower under all mulch types than unmulched handweeded and unweeded plots in both years. Among the mulch types, plastic mulch gave the least moisture loss. 


\section{R. O. Awodoyin \& S. Ogunyemi}

Table 6. Percentage of moisture depletion in the soil under various mulch treatments in 1997 and 1998. Values shown are means \pm S.E. $(n=4)$.

\begin{tabular}{lcl}
\hline Mulch treatment & $\mathbf{1 9 9 7}$ & $\mathbf{1 9 9 8}$ \\
\hline & & \\
Senna Interplant & $52.76 \pm 1.16$ & $69.10 \pm 1.83$ \\
Plastic Mulch & $11.06 \pm 0.31$ & $11.96 \pm 0.55$ \\
Grass Mulch & $51.56 \pm 0.46$ & $65.68 \pm 1.25$ \\
Woodchip Mulch & $42.14 \pm 1.44$ & $56.75 \pm 1.19$ \\
Handweeding & $68.15 \pm 0.93$ & $73.13 \pm 2.08$ \\
Unweeded & $59.81 \pm 0.36$ & $75.08 \pm 1.10$ \\
LSD (0.05) & 2.65 & 4.01 \\
CV(\%) & 3.69 & 4.54 \\
\hline
\end{tabular}

\section{Correlation}

The fruit yield of the pepper plants positively correlated with the plant height $(r=0.823)$, canopy width $(r=0.876)$ and number of fruits per plant $(r=0.986)$, and negatively correlated with weed dry weight $(r=-0.378)$ and moisture depletion $(r=-0.519)$ (Table 7). The number of fruits per plant positively correlated with the plant height $(r=0.820)$ and canopy width $(r=0.877)$. The weed dry weight, soil temperature at $5 \mathrm{~cm}$ depth at $1600 \mathrm{~h}$ and moisture depletion all negatively correlated with the growth and yield parameters of the pepper plants.

Table 7. Correlation coefficient (r) between growth and yield components of cayenne pepper, weed dry weight, $1600 \mathrm{~h}$ soil temperature and moisture depletion as affected by mulch treatments at Ibadan, Southwest Nigeria.

\begin{tabular}{|c|c|c|c|c|c|c|c|}
\hline & 1 & 2 & 3 & 4 & 5 & 6 & 7 \\
\hline Plant height (cm) [1] & - & $\begin{array}{l}0.910 \\
* * *\end{array}$ & $0.820 * *$ & $\begin{array}{c}0.823 \\
* * *\end{array}$ & -0.313 & -0.278 & $\begin{array}{c}- \\
0.270\end{array}$ \\
\hline Canopy width (cm) [2] & & - & $0.877 * * *$ & $\begin{array}{c}0.876 \\
* * *\end{array}$ & -0.327 & -0.284 & $\overline{-}-$ \\
\hline Number of fruits [3] & & & - & 0.986 & -0.345 & -0.072 & $\begin{array}{c}- \\
0.407\end{array}$ \\
\hline Fruit yield (t/ha.) [4] & & & & - & -0.378 & -0.029 & $\begin{array}{c}- \\
0.521\end{array}$ \\
\hline Weed dry weight $\left(\mathrm{g} / \mathrm{m}^{2}\right)$ [5] & & & & & - & -0.576 & $\begin{array}{c}- \\
0.519\end{array}$ \\
\hline $\begin{array}{l}1600 \text { h soil temperature at } 5 \\
\text { cm depth }\left({ }^{\circ} \mathrm{C}\right)[6]\end{array}$ & & & & & & - & $0 . \overline{2} 2$ \\
\hline $\begin{array}{l}\text { Soil Moisture depletion (\%) } \\
\text { [7] }\end{array}$ & & & & & & & - \\
\hline
\end{tabular}

\section{Discussion}

All mulch materials considerably improved the growth of cayenne pepper compared to unweeded and unmulched handweeding treatments. Aiyelaagbe and
Fawusi (1986) reported that mulched pepper plants were significantly larger than unmulched plants due to high water potential under mulches. Opara-Nadi (1993) demonstrated that protecting the soil surface with mulch improves the soil 
Emir. J. Agric. Sci. 2005. 17 (1): 10-22 http://www.cfa.uaeu.ac.ae/Research/EJAS.htm

environment for optimal crop growth and yield. However, woodchip mulch was inferior to other mulch materials in improving crop growth.

The comparable vegetative growth of unmulched handweeded plants with that of mulched treatments in 1997 may be due to the favourable moisture supply in the year. In 1998 with low and poorly distributed rainfall and the consequent intense water stress (rainfall:evaporation ratio $=1: 0.64)$, the mulched plants had better growth than unmulched plants. Aiyelaagbe and Fawusi (1986) reported that mulches become more important to plant growth when there is water stress. Also, Daisley et al. (1988) showed that mulching is an indispensable cultural practice in arid and semi-arid regions where limited and erratic rainfall often result in low yields.

The relatively good fruit yield of pepper plants that received organic mulch (Senna and grass mulches) may be due to the enhanced growth resulting from improved plant environment. Organic mulch has been reported to restore organic matter and plant nutrients to the soil, improves the soil structure and its water holding capacity, ameliorates soil temperature, controls soil losses and reduces weed pressure (Salau et al., 1992; Opara-Nadi 1993; Hudu et al., 2002). The high pepper yield under plastic mulch in both years compares with the results obtained for tomato and cayenne pepper mulched under drip irrigation (Liu et al., 1987). In 1998, the significantly low fruit yield observed in Senna-interplant plots compared to grass and plastic mulch, may be due to greater water stress in the year. The Senna interplant probably competed with pepper plants for water. This implies that interplanting cayenne pepper with $S$. obtusifolia will be beneficial only when moisture supply is not limiting.

In spite of the enhanced soil moisture content and reduced soil temperature under woodchip mulch, the pepper fruit yield was low and similar to that in unmulched handweeded plants. This may be due to shortfall in the supply of essential nutrients, especially nitrogen, as a result of immobilization and low nutrient turnover (Owaiye, 1993).

The low weed dry matter from mulched plots was due in part to the mechanical hindrance to weed emergence and establishment by mulch ground cover. Similar results have been reported by Salau et al. (1992), De Rouw (1995) and Hudu et al. (2002). The excellent weed control effect of plastic mulch was due to interception and reflection of solar radiation that could have induced light stimulation of weed seed germination, supra-optimal temperature and mechanical hindrance to seedling growth created by the film. The higher weed dry weight in grass mulch than in woodchip mulch may be due to better ground cover arising from closer packing of woodchip as well as greater persistence of the wood material than the cover of grass straws. This result agrees with the findings of Aiyelaagbe and Fawusi (1986) that sawdust controlled weeds better than dry grass and maize cob mulch. The low weed dry weight in Senna-interplant resulted from a combination of rapid canopy development and mechanical hindrance of pruning to weed seed germination and growth. De Rouw (1995) reported that the rapidity of fallow plants to develop overhead shade accounts for their success as weed break.

The high topsoil temperatures recorded under plastic mulch at all hours 


\section{R. O. Awodoyin \& S. Ogunyemi}

of the day in 1997 and 1998 conform with the report by Opara-Nadi (1993) that at $5 \mathrm{~cm}$ depth soil temperatures were highest under plastic mulch between $0800 \mathrm{~h}$ and $1800 \mathrm{~h}$. The grass and woodchip mulch reduced soil temperature, especially at the $5 \mathrm{~cm}$ soil depth by preventing direct contact of soil with dry air. The low temperature under Senna-interplant may be explained by the prevention of direct contact of soil with dry air by the mulch pruning and interception of incoming solar radiation by the plant canopy.

The lower moisture depletion in Senna-interplant plots than in unweeded plots in the two years may be due to the recurrent pruning that reduced water loss through transpiration and the ground cover provided by the pruning. The low moisture depletion under the teak woodchip mulch may be explained by its slow decomposition and long persistence on the soil.

The correlation studies indicate that reduced weed infestation, soil temperature and moisture depletion achieved by mulching resulted in good performance of pepper plants. This conforms with the findings of Hudu et al. (2002).

\section{Conclusion}

S. obtusifolia could be interplanted with slow-growing and shallow-rooted crops like cayenne pepper to generate mulch in situ through recurrent pruning. The Senna canopy and mulch cover effectively suppressed weeds, conserved soil moisture and regulated soil temperature in this crop. The thinning and recurrent pruning of Senna interplants probably reduced the above-ground Senna competition with pepper plants. The use of S. obtusifolia for in situ mulch generation will reduce the labour requirement for transporting and distributing mulch materials that has made generation of mulch ex situ less attractive.

\section{References}

Aiyelaagbe, I. O. O. and M. O. A. Fawusi. 1986. Growth and yield response of pepper to mulching. Biotronics 15:25-29.

Akobundu, I. O. 1993. Integrated weed management techniques to reduce soil degradation. IITA Research 6: 11-15.

Allen, S. E., H. M. Grimshaw, J. A. Parkinson and C. Quarmby. 1976. Chemical analysis of ecological material. Blackwell Scientific Publications. Oxford. 565 pp.

Anonymous 1987. Advances in fruit and vegetable Research at NIHORT (1976-86). National Horticultural Research Institute, Ibadan.

Awodoyin, R. O. and S. Ogunyemi. 2003. Sicklepod in improved fallow management: Distribution in natural habitat, diversity and phenology Muarik Bulletin 6:35-43.

Daisley, L. E. A., S. K. Chong, F. J. Olsen, L. Singh and C. George. 1988. Effects of surface applied grass mulch on soil water content and yields of cowpea and eggplant in Antigua. Trop. Agric. (Trinidad) 65:300-310.

De Rouw, A. 1995. The fallow period as a weed - break in shifting cultivation (tropical wet forest). Agric. Ecosystem Envt. 54:31-43. 
Emir. J. Agric. Sci. 2005.17 (1): 10-22

http://www.cfa.uaeu.ac.ae/Research/EJAS.htm

Fawusi, M. O. A. 1978. Emergence and seedling growth of pepper as influnced by soil compaction nutrient status and moisture regime. Scientia Horticulturae 9:329-335.

Gill, H. S. and V. Kumar. 1966. Weed Index. A new method for reporting weed control trials. Indian Journal of Agronomy 14:96-98.

Gomez, K. A. and A. A. Gomez. 1984. Statistical Procedures for Agricultural Research. John Wiley and Sons, New York. 2nd ed. 680 pp.

Greig-Smith, P. 1964. Quantitative Plant Ecology. Blackwell Scientific Publications, Oxford. $3^{\text {rd }}$ ed.

Hudu, A. I., K. N. Futuless and N. A. Gworgwor. 2002. Effects of mulching intensity on the growth and yield of irrigated tomato (Lycopersicon esculentum Mill.) and weed infestation in semi-arid zone of Nigeria. Journal of Sustainable Agriculture 21:37-45.

Kang, B. T. and B. S. Ghuman. 1991. Alley cropping and sustainable systems. In: W.C., Juson, N.W., Sheng, T.C. and Wei, L. Sam. (Eds.). Development of conservation farming on Hillslope, Moldenhaver. Soil Water Conservation Society, Iowa, USA.

Kang, B. T., G. F. Wilson and L. Sipkens. 1981. Alley cropping maize (Zea mays) and leucaena (Leucaena leucocephala) in Southern Nigeria. Plant and Soil 63:165-179.

Kotschi, J. 1990. Introduction. In: PP. 1-5. J. Kotschi (Ed.), Ecofarming practices for tropical Smallholdings, Verlag josef margrave.

Little, T. M. and F. J. Hills. 1978. Agricultural Experimentation: Design and Analysis. John Wiley \& Sons. New York. 350 pp.

Liu, L. C., M. Antoni-Padilla, M. R. Goyal and J. Gonzalez-Ibanez. 1987. Integrated weed management in transplanted tomatoes and peppers under drip irrigation. J. Agric., Univ. of Puerto Rico 71:349-358.

Messiaen, C.M. 1992. The tropical vegetable garden: principles for improvement. Macmillan Ltd., United Kingdom. 514 pp.

Opara-Nadi, O. A. 1993. Effect of elephant grass and plastic mulch on soil properties and cowpea yield. In: Mulongoy, K. and Merckx, R. (eds.), Soil organic matter dynamics and sustainability of Tropical Agriculture, John Wiley \& Sons, New York. p. 351-360.

Owaiye, A. R. 1993. Effect of residue mulch on characteristics and productivity of two soil classes under coffee in Nigeria. p. 339-343. In: Mulongoy, K. and Merckx, R. (Eds.), Soil Organic Matter Dynamics and Sustainability of Tropical Agriculture. John Wiley \& Sons, New York.

Salau, O. A., O. A. Opara-Nadi and R. Swennen. 1992. Effects of mulching on soil properties, growth and yield of plantain on a tropical ultisol in South Eastern Nigeria. Soil Tillage Research 23:73-93. 